\title{
Development of a PCR assay for detection of the oyster pathogen Bonamia ostreae and support for its inclusion in the Haplosporidia
}

\author{
Ryan B. Carnegie ${ }^{1, *}$, Bruce J. Barber ${ }^{1}$, Sarah C. Culloty ${ }^{2}$, Antonio J. Figueras ${ }^{3}$, \\ Daniel L. Distel ${ }^{1,4}$
}

${ }^{1}$ School of Marine Sciences and ${ }^{4}$ Department of Biochemistry, Microbiology, and Molecular Biology, University of Maine, Orono, Maine 04469, USA

${ }^{2}$ Dept of Zoology and Animal Ecology, University College Cork, Lee Maltings, Prospect Row, Cork, Ireland

${ }^{3}$ Instituto de Investigaciones Marinas, CSIC, Eduardo Cabello, 6, 36208 Vigo, Pontevedra, Spain

\begin{abstract}
The development of diagnostic assays more sensitive and specific than traditional histological techniques is important for the management of bonamiasis in flat oysters Ostrea edulis. A specific polymerase chain reaction (PCR) protocol was developed for the detection of very small amounts of Bonamia ostreae (Pichot et al. 1980) ribosomal DNA (rDNA) in bulk DNA from oyster gill and hemolymph. The presence of a $760 \mathrm{bp}$ PCR amplification product corresponded with $B$. ostreae infections determined cytologically in 185 oysters from Ireland, Spain, and the USA. All $(100 \%)$ 'heavily' and 'moderately' infected oysters, $86.7 \%$ of the 'lightly' infected oysters, and $66.7 \%$ of the 'scarcely' infected oysters were confirmed to be infected using the PCR. In addition, $37.9 \%$ of the oysters in which $B$. ostreae was not detected using cytology were positive using the PCR. Sampling error and the subjectivity of cytological diagnoses are the likely sources of disagreement between diagnostic methods in oysters with very light infections. The PCR assay developed here is more sensitive and less ambiguous than standard histological and cytological techniques. Phylogenetic analysis of DNA sequence data confirmed B. ostreae to be a member of the Haplosporidia.
\end{abstract}

KEY WORDS: Bonamia ostreae $\cdot \mathrm{PCR} \cdot$ Haplosporidia $\cdot$ Ostrea edulis

\section{INTRODUCTION}

Bonamia ostreae (Pichot et al. 1980) is a protistan pathogen of flat oysters Ostrea edulis Linné in Europe (Pichot et al. 1980, Balouet et al. 1983, Montes 1990, McArdle et al. 1991, Hudson \& Hill 1991, van Banning 1991), on the Pacific coast of the USA (Elston et al. 1986, Friedman et al. 1989), and in Maine, USA (Barber \& Davis 1994, Friedman \& Perkins 1994). Its phylogenetic relationship to other protists is uncertain. Although the possession of haplosporosomes suggests an affinity to the Haplosporidia (Pichot et al. 1980,

*E-mail: ryan.carnegie@umit.maine.edu
Perkins 1990), B. ostreae does not form spores (Pichot et al. 1980), which are considered primary diagnostic characters of this phylum (Sprague 1979).

Rapid and accurate diagnosis of Bonamia ostreae is essential to the management of bonamiasis in wild and cultured oyster populations. Standard diagnosis is performed with fixed and stained tissue sections (histopathology). Detection using fixed and stained heart and hemolymph smears (cytology) is more rapid and less expensive, and considered useful for the preliminary screening of oyster populations (Zabaleta \& Barber 1996, O'Neill et al. 1998). A major disadvantage of standard histopathology and cytology is low sensitivity. The small size of $B$. ostreae (2 to $3 \mu \mathrm{m}$ ) makes it difficult to recognize subclinical infections in thin sec- 
tions, and several investigators have reported trouble detecting $B$. ostreae at low intensity in stained blood smears (Bucke \& Feist 1985, Bucke 1988, McArdle et al. 1991). In addition, the resemblance of $B$. ostreae to routine intrahemocytic inclusions (Bucke \& Feist 1985) makes false positive microscopic diagnosis a possibility. Sensitive and specific immunohistological diagnostic methods have been developed for B. ostreae (Boulo et al. 1989, Rogier et al. 1991, Cochennec et al. 1992). However, the antibodies developed for $B$. ostreae in Europe react weakly or not at all with $B$. ostreae from populations outside of Europe (Zabaleta \& Barber 1996), suggesting that serological differences in $B$. ostreae between locations and possibly over time may limit the usefulness of this tool.

DNA probes and polymerase chain reaction (PCR) assays have been developed for numerous bivalve parasites, including Haplosporidium nelsoni (Fong et al. 1993, Stokes \& Burreson 1995, Stokes et al. 1995a), Minchinia teredinis (Stokes et al. 1995b), Marteilia sydneyi (Anderson et al. 1995), Mikrocytos roughleyi (Adlard \& Lester 1995), and most recently Bonamia ostreae (Carnegie et al. 1999). We describe here the development of a PCR assay for detection of $B$. ostreae in Ostrea edulis, based on $18 \mathrm{~S}$ ribosomal DNA (rDNA) sequences conserved between $B$. ostreae populations in Europe and the USA, and provide molecular evidence supporting the affinity of $B$. ostreae to the Haplosporidia.

\section{MATERIALS AND METHODS}

Oysters were collected from Cork Harbour, Ireland, in November 1997 ( $\mathrm{n}=71$ ); Gun Point Creek, Maine, in August 1999 and October 1999 ( $\mathrm{n}=47$ and 37, respectively); and Ria de Arosa, Spain, in January 2000 $(\mathrm{n}=30)$, where Bonamia ostreae is enzootic (Montes 1990, Barber \& Davis 1994, Culloty \& Mulcahy 1996, O'Neill et al. 1998). Ostrea edulis from Spinney Creek, Maine $(\mathrm{n}=30)$, and juvenile Crassostrea virginica from the Great Wicomico River, Virginia $(n=19)$, served as negative controls, as $B$. ostreae has never been detected at these locations. Haplosporidium nelsoni (MSX) spores were observed in $5 \%$ of juvenile Great Wicomico River C. virginica at the time of sampling (Nancy Stokes, Virginia Institute of Marine Sciences, pers. comm.).

The right or upper valve of each oyster was removed, and either $\sim 0.1-0.5 \mathrm{~g}$ gill tissue was excised or $200 \mu \mathrm{l}$ hemolymph drawn (or both) for genomic DNA extraction (see below). Hemocytes were then prepared for cytological diagnosis of Bonamia ostreae. Ventricles from Cork Harbour oysters and gill fragments from Ria de Arosa oysters were removed, blotted on tissue paper, then dabbed on a glass microscope slide. Cells were fixed in methanol and stained with Hemacolor (Merck) rapid blood stain (Culloty \& Mulcahy 1996). For Gun Point Creek and Spinney Creek oysters, fluid from the pericardial cavity was withdrawn and mixed 1:5 to $1: 10$ with $0.45 \mu \mathrm{m}$ filtered ambient seawater. A drop of this suspension was placed on a microscope slide. Cells were given $15 \mathrm{~min}$ to adhere, then fixed and stained using Hemostat (Fisher Scientific) solutions (Zabaleta \& Barber 1996). Slides were examined microscopically for 5 min at 400-1000× magnification. Infections were scored as 'heavy' if all observed hemocytes contained B. ostreae; 'moderate' if B. ostreae was visible in all microscope fields; 'light' if 11 to $100 \mathrm{~B}$. ostreae were observed within $5 \mathrm{~min}$; 'scarce' if 1 to 10 $B$. ostreae were observed; and 'undetected' if no unambiguous $B$. ostreae were observed (Bachère et al. 1982, Culloty \& Mulcahy 1996).

Genomic DNA from Cork Harbour oysters was extracted as follows. Gill fragments ( 0.1 g) fixed in $95 \%$ ethanol were rinsed twice in $\mathrm{ddH}_{2} \mathrm{O}$ and minced, then incubated overnight at $55^{\circ} \mathrm{C}$ in a digestion solution of $0.05 \mathrm{M}$ Tris-HCl, $0.2 \mathrm{M} \mathrm{NaCl}, 0.05 \mathrm{M}$ EDTA, 1\% SDS, and $0.05 \mathrm{mg} \mathrm{ml}^{-1}$ Proteinase $\mathrm{K}$ at $\mathrm{pH}$ 8.0. After a single extraction with phenol and 2 with chloroform:isoamyl alcohol (24:1), DNA was precipitated with absolute ethanol:3 M ammonium acetate (11:1) and quantified spectrophotometrically. For Gun Point Creek, Spinney Creek, and Great Wicomico River oysters, DNA was extracted from $200 \mu \mathrm{l}$ of hemolymph using a QIAamp DNA Mini Kit (QIAGEN Inc.) following the manufacturer's Blood and Body Fluid Spin Protocol. For Ria de Arosa oysters, DNA was extracted from $\sim 0.1 \mathrm{~g}$ of gill tissue using a QIAamp DNA Mini Kit following the manufacturer's Tissue Protocol. To compare PCR results based on DNA extraction from gill with those based on extraction from hemolymph, an additional extraction using gill tissue of 37 Gun Point Creek Ostrea edulis (October 1999) was performed using a QIAamp DNA Mini Kit following the manufacturer's Tissue Protocol.

The PCR-based part of this study comprised 2 phases, one of PCR protocol development and one of confirmation of the specificity and sensitivity of the final PCR protocol. The development phase proceeded in a stepwise fashion, first using the PCR to amplify candidate protistan rDNA fragments from a bulk genomic DNA mixture (Protocol A), then sequencing an amplicon that appeared to correspond with Bonamia ostreae infections, and finally using 2 increasingly more specific PCR protocols (Protocols B and C) to establish the identity of the putative B. ostreae amplicon. Each PCR protocol in this development phase used template DNA from Cork Harbour oysters $(n=71)$, but differed from the others in PCR primer sequence and annealing temperature (Table 1, Fig. 1). Reaction conditions were 
Table 1. Primer sequences, annealing temperatures, and predicted amplicon sizes of PCR Protocols A, B, and C. $T_{\mathrm{m}}=$ annealing temperature

\begin{tabular}{|c|c|c|c|}
\hline $\begin{array}{l}\text { Proto- } \\
\text { col }\end{array}$ & Primers & $\begin{array}{l}T_{\mathrm{m}} \\
\left({ }^{\circ} \mathrm{C}\right)\end{array}$ & $\begin{array}{l}\text { Product } \\
\text { size }(b p)\end{array}$ \\
\hline A & $\begin{array}{l}A_{F}: \text { TGTGATGCCCTTAGATGTYCT } \\
A_{R}: \text { GCTGCGTCCTTCATCGWT }\end{array}$ & 55 & 528 \\
\hline B & $\begin{array}{l}\mathrm{B}_{\mathrm{F}}: \text { CAGCCRTCTAACTAGCTSTCGC } \\
\mathrm{B}_{\mathrm{R}}: \text { CGGGTCAAACTCGTTGAACG }\end{array}$ & 55 & 122 \\
\hline $\mathrm{C}$ & $\begin{array}{l}\mathrm{C}_{\mathrm{F}}: \text { CGGGGGCATAATTCAGGAAC } \\
\mathrm{C}_{\mathrm{R}}: \text { CCATCTGCTGGAGACACAG }\end{array}$ & 59 & 760 \\
\hline
\end{tabular}

parasite, Mikrocytos roughleyi (Adlard \& Lester 1995). Degenerate primers $\left(A_{F}\right.$ and $A_{R i}$ see Table 1) were designed by aligning several 18S-ITS 1 rDNA sequences deposited in Genbank (Ostrea edulis [gb U88709], Arion rufus [gb X00131], Stagnicola elodes [gb AF013138], Drosophila orena [gb Z28549], Saccharomyces bayanus [gb Z95945], Amphidinium belauense [gb L13719], Alexandrium affine [gb AB006995], Alexandrium catenella [gb AB006990], Alexandrium insuetum [gb AB006996], Alexandrium minutum [gb U27499], Alexandrium pseudogonyaulax [gb AB006997], Alexandrium tamarense [gb AB006991], Crypthecodinium cohnii [gb M25116], Gonyaulax spinifera [gb AF051832], Gymnodinium sanguineum [gb U41085], Perkinsus atlanticus [gb U07697], Perkinsus marinus [gb X75762 and U07700], Perkinsus olseni [gb U07701], Perkinsus sp. [gb U07698], Scrippsiella nutricula [gb U52357], Symbiodinium pilosum [gb X62650], Cryptosporidium parvum [gb L25642 and AF040725], Eimeria maxima [gb AF027723], Giardia ardeae [gb X58290 M38598 M73684 M73685], Neospora caninum [gb L49389], Oxytricha nova [gb X03948 M14601], Plasmodium falciparum [gb U21939], Plasmodium malariae [gb M54890], Prorocentrum micans [gb M14649], Theileria parva [gb L26331], Toxoplasma gondii [gb L37415 and L49390], Colpidium campylum [gb M35557], Colpidium colpoda [gb M35558], Glaucoma chattoni [gb M35559], Tetrahymena corlissi [gb U17356], Tetrahymena leucophrys [gb M35555], Tetrahymena paravorax [gb M35556], Tetrahymena patula [gb M35553], Tetrahymena pyriformis [gb X01533 M10752], Tetrahymena vorax [gb M35554], and Haplosporidium nelsoni [gb U19538]) using GDE (Wisconsin Package Version 9.0, Genetics Computer Group [GCG], Madison, WI) and were commercially synthesized (Operon Technologies, Inc., Alameda, CA). Although the length of a $B$. ostreae sequence generated by this protocol could not be predicted, an $O$. edulis amplicon of $\sim 1000 \mathrm{bp}$ in size was predicted. PCR products longer or shorter than this could thus be considered candidate $B$. ostreae sequences. A single $528 \mathrm{bp}$ fragment amplified from 14 of 71 Cork Harbour oysters was cloned using a TOPO TA Cloning Kit (Invitrogen) and sequenced at the University of Maine DNA Sequencing Facility. This amplicon occurred coincident with heavier B. ostreae infections, and a Genbank Blast search indicated a resemblance of this product to haplosporidian 18S rDNA, making it a strong candidate for $B$. ostreae rDNA.

The second PCR protocol (Protocol B) was specific for the putative Bonamia ostreae fragment previously amplified. Primers $\left(\mathrm{B}_{\mathrm{F}}\right.$ and $\mathrm{B}_{\mathrm{R} i}$ Table 1$)$ were designed by aligning this sequence with oyster (Ostrea edulis

Fig. 1. Diagrammatic representation of the PCR assay development. The PCR product of Protocol A could not be predicted a priori. This $528 \mathrm{bp}$ product represents the single candidate Bonamia ostreae PCR amplicon resulting from this assay. The Protocol B amplicon was predicted based on alignment of the amplicon A sequence with several haplosporidian sequences (see text). The Protocol $\mathrm{C}$ amplicon was predicted based on the complete putative $B$. ostreae 18S-ITS 1 rDNA sequence 
[gb U88709]) and haplosporidian (Haplosporidium nelsoni [gb U19538], Haplosporidium louisiana [gb U47851], Minchinia teredinis [gb U20319], and Urosporidium crescens [gb U47852]) sequences identified by Genbank Blast search to be most similar to it. The reverse primer targeted a sequence that diverged from known haplosporidian sequences, and the forward primer was designed to bind to a consensus haplosporidian sequence. A positive signal for putative $B$. ostreae rDNA was indicated by the presence of a 122 bp amplicon.

PCR Protocol C was also specific for putative Bonamia ostreae rDNA. Protocol C was designed following amplification (conditions as above; forward primer sequence WAYCTGGTTGATCCTGCCAGT [Medlin et al. 1988], reverse primer $A_{R}$, annealing temperature = $55^{\circ} \mathrm{C}$ ) and sequencing of the entire putative $B$. ostreae 18S-ITS 1 rDNA sequence (submitted to Genbank under accession no. AF262995) from 1 Gun Point Creek and 3 Cork Harbour oysters. (These 4 sequences diverged by just $0.39 \%$ over $1945 \mathrm{bp}$ of $18 \mathrm{~S}$ and ITS 1.) Both forward and reverse $\left(C_{F}\right.$ and $C_{R i}$ Table 1) primer sequences were exact matches for the putative $B$. ostreae target sequence. A $760 \mathrm{bp}$ product was predicted. A final evaluation of Cork Harbour oysters with Protocol C was performed.

To confirm the sensitivity of Protocol C, oysters from Gun Point Creek (low Bonamia ostreae prevalence; light infection intensity) and Ria de Arosa (higher $B$. ostreae prevalence; full range of infection intensities) were screened. To assess the specificity of Protocol C, control oysters (Ostrea edulis and Crassostrea virginica, the latter not a host for B. ostreae) from areas in which B. ostreae is not enzootic (Spinney Creek and Great Wicomico River, respectively) were screened.

Seventeen alveolate 18S rDNA sequences (Alexandrium belauense [gb L13719], Crypthecodinium cohnii [gb M64245 M34847], Perkinsus marinus [gb X75762], Prorocentrum micans [gb M14649], Symbiodinium corculorum [gb L13717], Cryptosporidium serpentis [gb AF151376], Theileria annulata [gb M64243 M-
34845], Toxoplasma gondii [gb X75429], Oxytricha nova [gb X03948 M14601], Paramecium tetraurelia [gb X03772], Tetrahymena pyriformis [gb M98021], Stylonichia pustulata [gb M14600], Haplosporidium costale [gb U20858], H. louisiana [gb U47851], H. nelsoni [gb X74131], Minchinia teredinis [gb U20319], and Urosporidium crescens [gb U47852]) were aligned with the putative Bonamia ostreae 18S gene using CLUSTAL W (Thompson et al. 1994) and refined by eye, using Genedoc (Nicholas \& Nicholas 1997) and taking secondary structure into account, for phylogenetic analysis. Length variable sequences of uncertain positional homology, corresponding with $T$. pyriformis (gb M98021) bases 65-70, 121-130, 169-239, 261-273， 469-490， 626-716， 750-760, 792-798, 815-818, 1012-1023, 1306-1329, 1344-1357, 1429-1485, and 1625-1654, were excluded from the analysis. Unweighted maximum parsimony analysis was performed on 1121 aligned positions using PAUP (phylogenetic analysis using parsimony) (Swofford 1999). Taxa were added to the resulting trees by stepwise addition, with the tree-bisection-reconnection branch swapping algorithm in use. Bootstrap proportions (100 replicates) for resulting trees were calculated using PAUP's heuristic bootstrap search function.

\section{RESULTS}

PCR Protocols A, B, and C generated amplicons of the predicted sizes, presumably Bonamia ostreae rDNA, in $19.7,22.5$, and $63.4 \%$, respectively, of Cork Harbour oysters. Diagnosis using ventricular hemolymph smears revealed a putative $B$. ostreae prevalence of $53.5 \%$.

Table 2 illustrates the frequency with which each protocol generated a putative Bonamia ostreae amplicon in Cork Harbour oysters pooled by cytological infection intensity score. Among oysters of a given infection intensity, Protocol C was more frequently positive for putative $B$. ostreae (and thus more sensitive) than Protocol B, and similarly, Protocol B was

Table 2. Percentage of detection of a putative Bonamia ostreae PCR amplicon in Cork Harbour, Ria de Arosa, and Gun Point Creek oysters (August and October 1999 samples pooled) grouped by cytological infection intensity score. Example: $72.7 \%$ under Cork Harbour, Protocol B indicates that this protocol detected B. ostreae in 8 of 11 or $72.7 \%$ of oysters diagnosed using cytology as harboring 'moderate' B. ostreae infections. na: not applicable

\begin{tabular}{|c|c|c|c|c|c|c|c|c|c|c|}
\hline \multirow[t]{2}{*}{ Intensity } & \multirow[b]{2}{*}{$\mathrm{n}$} & \multicolumn{2}{|c|}{ Cork Harbour } & \multirow[b]{2}{*}{ Protocol C } & \multicolumn{2}{|c|}{ Ria de Arosa } & \multicolumn{2}{|c|}{ Gun Point Creek } & \multicolumn{2}{|c|}{ Overall } \\
\hline & & Protocol A & Protocol B & & $\mathrm{n}$ & Protocol C & $\mathrm{n}$ & Protocol C & $\mathrm{n}$ & Protocol C \\
\hline Heavy & 5 & 100 & 100 & 100 & 3 & 100 & 0 & na & 8 & 100 \\
\hline Moderate & 11 & 63.6 & 72.7 & 100 & 4 & 100 & 1 & 100 & 16 & 100 \\
\hline Light & 8 & 12.5 & 25.0 & 87.5 & 5 & 100 & 2 & 50.0 & 15 & 86.7 \\
\hline Scarce & 14 & 0.0 & 0.0 & 50.0 & 8 & 87.5 & 8 & 75.0 & 30 & 66.7 \\
\hline Undetected & 33 & 3.0 & 3.0 & 45.5 & 10 & 50.0 & 73 & 32.9 & 116 & 37.9 \\
\hline
\end{tabular}


more sensitive than Protocol A. Oysters diagnosed as heavily infected were always associated with a positive PCR signal for putative $B$. ostreae regardless of protocol used. In oysters with lighter infections, however, a positive PCR signal was less frequently present. Cork Harbour oysters in which $B$. ostreae was not detected microscopically were rarely positive $(3.0 \%)$ for putative B. ostreae using PCR Protocols A and B, but often positive $(45.5 \%)$ using Protocol C. The Protocol C results using Ria de Arosa oysters mirrored those from Cork Harbour (Table 2). The putative B. ostreae amplicon was detected in every 'heavily', 'moderately', or 'lightly' infected oyster, most (87.5\%) 'scarcely' infected oysters, and half of those $(50.0 \%)$ in which $B$. ostreae was not detected cytologically. The Protocol C results using Gun Point Creek oysters were less illustrative, as these oysters displayed a narrow range of infection intensities. However, as in the trials using oysters from Cork Harbour and Ria de Arosa, a putative B. ostreae amplicon was observed in most (75.0\%) 'scarcely' infected oysters, and many (32.9\%) of those considered 'uninfected'. In total, 57 of the 69 oysters $(82.6 \%)$ determined to be infected using cytology were confirmed to contain putative $B$. ostreae rDNA using Protocol C. In addition, 44 of 116 oysters (37.9\%) thought to be uninfected as determined using cytology actually harbored putative $B$. ostreae rDNA (Table 2).

Overall prevalence of Bonamia ostreae at locations examined in this study using PCR Protocol C was greater than that determined using cytology (Fig. 2). In addition, B. ostreae has never been detected microscopically in control Spinney Creek Ostrea edulis, and it was not detected in these and Great Wicomico River Crassostrea virginica using Protocol C (Fig. 2).

Prevalence of putative Bonamia ostreae in 37 Gun Point Creek oysters was the same using either gill

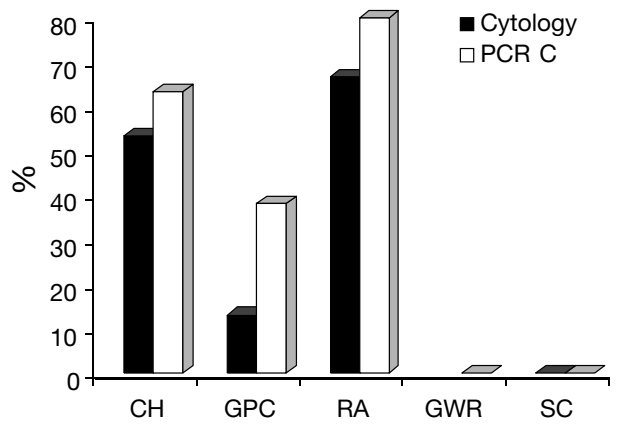

Fig. 2. Bonamia ostreae prevalence in 5 Ostrea edulis samples and 1 Crassostrea virginica sample (GWR) determined using standard cytology and PCR Protocol C. Experimental (known $B$. ostreae enzootic) groups: $\mathrm{CH}=$ Cork Harbour; $\mathrm{GPC}=$ Gun Point Creek; RA = Ria de Arosa. Control (presumed $B$. ostreae-free) groups: GWR = Great Wicomico River; $\mathrm{SC}=$ Spinney Creek
DNA or hemolymph DNA as a PCR template. However, in 3 oysters the gill sample was positive for putative $B$. ostreae and the hemolymph sample was not, and in another 3 the hemolymph sample was positive and the gill was not.

Phylogenetic analysis using 366 parsimony-informative positions placed the putative Bonamia ostreae sequence within the Haplosporidia (Fig. 3) on a single most parsimonious tree (length $=1851)$. Bootstrap support was significant $(100 \%)$ for the monophyly of the Haplosporidia and also $(90 \%)$ for the placement of putative B. ostreae in an internal clade with Haplosporidium costale, $H$. nelsoni, Minchinia teredinis, and $H$. louisiana. This analysis did not resolve the branching order among these organisms.

\section{DISCUSSION}

The strong correspondence between the presence of putative Bonamia ostreae PCR amplicons and $B$. ostreae infections (determined cytologically) indicates that these PCR products indeed represent $B$. ostreae rDNA. 'Lightly', 'moderately', or 'heavily' infected oysters comprised just $33.8 \%$ of the Cork Harbour sample,

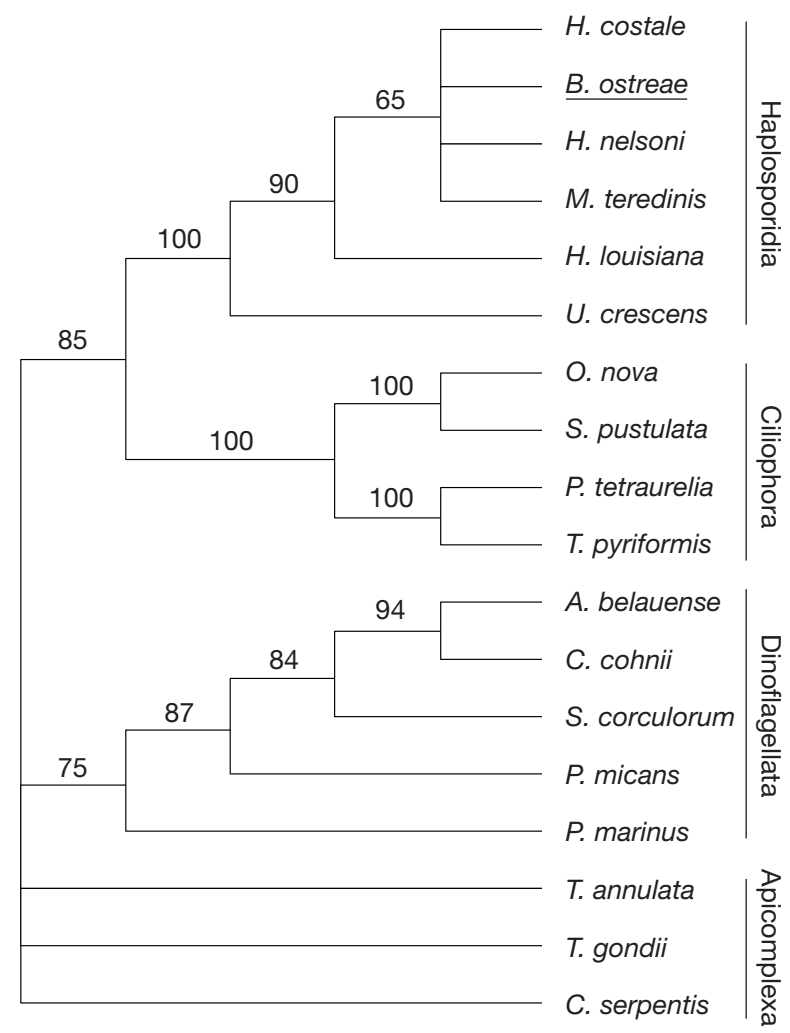

Fig. 3. A single most parsimonious tree, rooted with representatives of the Apicomplexa, resulting from unweighted maximum parsimony analysis. Numbers represent percentages of 100 bootstrap replicates 
yet were associated with $92.9 \%$ of the positive PCR Protocol A signals and $93.8 \%$ of those in Protocol B. All cytologically determined 'heavy' and 'moderate' $B$. ostreae infections were detected using Protocol $\mathrm{C}$, and 'light' infections were detected $86.7 \%$ of the time. A positive PCR signal for $B$. ostreae was never observed in control oysters from Spinney Creek and Great Wicomico River.

Although not quantitatively determined, the sensitivity of the PCR protocol increased from Protocol A through Protocol C, as the match of primer sequence to target Bonamia ostreae rDNA improved. Protocol A was expected to be less specific since primers $A_{F}$ and $A_{R}$ were designed to amplify a broad range of protistan rDNA from an oyster-protist mixture. Subsequent sequence analysis confirmed a primer-target mismatch to B. ostreae rDNA of 19.0 to $23.8 \%$ in the forward primer and 0.0 to $5.6 \%$ in the reverse. Accordingly, only relatively heavy $B$. ostreae infections were detected with this protocol. Protocol B was more sensitive, with a 13.7 to $22.7 \%$ forward primer-target mismatch and a perfect match of reverse primer-target. All the infections detected with Protocol A plus 2 additional infections were detected with Protocol B. Protocol C had a perfect primer-target match and was most sensitive, detecting all the infections detected with Protocols A and B, plus several more. A greater prevalence of $B$. ostreae was determined in all samples using PCR Protocol $\mathrm{C}$ as compared to cytology because of the superior sensitivity of the PCR in detecting very light infections.

Cytologically determined infection intensity is expected to correlate with the amount of Bonamia ostreae DNA in the PCR reaction mixture, i.e., DNA extracted from heavily infected oysters should contain comparatively larger amounts of parasite DNA. Furthermore, as hemocytes containing $B$. ostreae in heavily infected oysters are numerous and diffuse (Balouet et al. 1983, Bucke \& Feist 1985), any given tissue sample from such oysters is likely to contain B. ostreae cells. Both cytological techniques and PCR protocols of even low sensitivity (e.g., Protocol A) should detect B. ostreae in such samples. Lightly infected oysters, by comparison, would have relatively little parasite DNA, and because such infections are characterized by isolated, focal infiltrations, tissue samples from such oysters might not contain any parasite cells (and thus parasite DNA) at all. False negative results, attributable to sampling error, would thus be possible regardless of technique. Cytological techniques are additionally susceptible to false negative diagnoses because, when present at a very low intensity, $B$. ostreae may be mistaken for 'other intracytoplasmic inclusions or spermatozoa' (Bucke \& Feist 1985).

The likelihood of obtaining false negative PCR results for any single oyster may be reduced through parallel screening of multiple tissue samples. Alternatively, a post-PCR aliquot of reaction solution may be used as the template for a second PCR. When Bonamia ostreae rDNA initially amplifies weakly, this may increase the amount of PCR product to a detectable level. However, using these approaches often would erode the cost advantage PCR holds over histopathology, and make it substantially more expensive than cytology. Going to such lengths to prevent false negative diagnoses is not always necessary. The challenge for managers of bonamiasis is to determine when it is important, that is, to define an acceptable level of false negative diagnostic results for a given set of circumstances (e.g., for transfer of hatchery-produced seed to a $B$. ostreae-free nursery area).

The absence of amplification in Spinney Creek (where Bonamia ostreae has never been detected) and Great Wicomico River oysters (a species not susceptible to $B$. ostreae) suggests a low rate of false positive results (for B. ostreae and Haplosporidium nelsoni) using Protocol C. Thus, the high proportion (37.9\%) of positive PCR results with oysters determined to be uninfected using cytology was most likely the result of the inherent difficulty of making cytological diagnoses at very low infection intensities.

Several authors (e.g., Pichot et al. 1980, Perkins 1990) have proposed that the presence of haplosporosomes indicates a phylogenetic affinity of Bonamia ostreae to the Haplosporidia. Analysis of DNA sequence data indicates that $B$. ostreae is indeed a haplosporidian. In addition, the finding that the Haplosporidia forms a monophyletic sister clade to the Ciliophora supports the conclusions of Flores et al. (1996), who described the relationship of the Haplosporidia to other alveolate taxa. The branching order of $B$. ostreae with respect to other microcell protistans, Bonamia spp., Mikrocytos mackini and Mikrocytos roughleyi (Farley et al. 1988) awaits resolution. The similarity between Cork Harbour and Gun Point Creek B. ostreae 18S rDNA sequences indicates a single $B$. ostreae species at these locations.

The sensitive PCR assay described here, specific for Bonamia ostreae in Europe and North America, will be important in the management of bonamiasis for aquaculture wherever $B$. ostreae occurs. Large numbers of oysters may be rapidly and non-destructively screened for this parasite. (Forty adult oysters may be processed in as little as $8 \mathrm{~h}$ [including DNA extraction and PCR], a rate commensurate with cytology but faster than histopathology, which can take days.) This will be particularly useful when the absence of $B$. ostreae from a prospective culture location needs to be confirmed, or seed and broodstock need to be certified $B$. ostreaefree. An in situ analog of this protocol will be very useful in illuminating the life history of $B$. ostreae. 
Acknowledgements. We would like to thank Spinney Creek Shellfish (Eliot, Maine) and Nancy Stokes of the Virginia Institute of Marine Science for generously providing control oysters for this study. Dolores Dominguez and Begoña Villaverde provided technical support in the processing of the Ria de Arosa oysters. Danielle Baker helped with genomic DNA extractions and the PCR. Patty Singer and Karen Williams of the University of Maine DNA Sequencing Facility performed all sequencing. The manuscript was improved by the thoughtful comments of 3 anonymous reviewers. The work reported in this publication was supported in part by the Maine/New Hampshire Sea Grant Program and by the Northeastern Regional Aquaculture Center at the University of Massachusetts Dartmouth, through Grant No. 96-38500-3032 from the Cooperative State Research, Education, and Extension Service (CSREES) of the United States Department of Agriculture (USDA). This is Maine Agriculture and Forest Experiment Station external publication no. 2418.

\section{LITERATURE CITED}

Adlard RD, Lester RJG (1995) Development of a diagnostic test for Mikrocytos roughleyi, the aetiological agent of Australian winter mortality of the commercial rock oyster, Saccostrea commercialis (Iredale \& Roughley). J Fish Dis 18:609-614

Anderson TJ, Adlard RD, Lester RJG (1995) Molecular diagnosis of Marteilia sydneyi (Paramyxea) in Sydney rock oysters, Saccostrea commercialis (Angas). J Fish Dis 18: 507-510

Bachère E, Durand JL, Tige G (1982) Bonamia ostreae (Pichot et al., 1979) parasite de l'huître plate: comparison de deux methodes de diagnostic. ICES CM 1982/F28

Balouet G, Poder M, Cahour A (1983) Haemocytic parasitosis: morphology and pathology of lesions in the French flat oyster, Ostrea edulis L. Aquaculture 34:1-14

Barber BJ, Davis CV (1994) Prevalence of Bonamia ostreae in Ostrea edulis populations in Maine. J Shellfish Res 13:298

Boulo V, Mialhe E, Rogier H, Paolucci F, Grizel H (1989) Immunodiagnosis of Bonamia ostreae (Ascetospora) infection of Ostrea edulis L. and subcellular identification of epitopes by monoclonal antibodies. J Fish Dis 12:257-262

Bucke D (1988) Pathology of bonamiasis. Parasitol Today 4(6): 174-176

Bucke D, Feist S (1985) Bonamiasis in the flat oyster, Ostrea edulis, with comments on histological techniques. In: Ellis AE (ed) Fish and shellfish pathology. Academic Press, London, p 387-392

Carnegie RB, Barber BJ, Distel DL, Culloty SC (1999) Development of PCR and in situ hybridization assays for detection of Bonamia ostreae in flat oysters, Ostrea edulis. J Shellfish Res 18(2):711-712

Cochennec N, Hervio D, Panatier B, Boulo V, Mialhe E, Rogier H, Grizel H, Paolucci F (1992) A direct monoclonal antibody sandwich immunoprotocol for detection of Bonamia ostreae (Ascetospora) in hemolymph samples of the flat oyster Ostrea edulis (Mollusca: Bivalvia). Dis Aquat Org 12:129-134

Culloty SC, Mulcahy MF (1996) Season-, age-, and sexrelated variation in the prevalence of bonamiasis in flat oysters (Ostrea edulis L.) on the south coast of Ireland. Aquaculture 144:53-63

Elston RA, Farley CA, Kent ML (1986) Occurrence and significance of bonamiasis in European flat oysters Ostrea edulis in North America. Dis Aquat Org 2:49-54

Farley CA, Wolf PH, Elston RA (1988) A long-term study of 'microcell' disease in oysters with a description of a new genus, Mikrocytos (g. n.), and two new species, Mikrocytos mackini (sp. n.) and Mikrocytos roughleyi (sp. n.). Fish Bull 86(3):581-593

Flores BS, Siddall ME, Burreson EM (1996) Phylogeny of the Haplosporidia (Eukaryota: Alveolata) based on small subunit ribosomal RNA gene sequence. J Parasitol 82(4): $616-623$

Fong D, Chan MMY, Rodriguez R, Chen CC, Liang Y, Littlewood DTJ, Ford SE (1993) Small subunit ribosomal RNA gene sequence of the parasitic protozoan Haplosporidium nelsoni provides a molecular probe for the oyster MSX disease. Mol Biochem Parasitol 62:139-142

Friedman CS, Perkins FO (1994) Range extension of Bonamia ostreae to Maine, U.S.A. J Invertebr Pathol 64:179-181

Friedman CS, McDowell T, Groff JM, Hollibaugh JT, Manzer D, Hedrick RP (1989) Presence of Bonamia ostreae among populations of the European flat oyster, Ostrea edulis Linne, in California, USA. J Shellfish Res 8(1):133-137

Hudson EB, Hill BJ (1991) Impact and spread of bonamiasis in the UK. Aquaculture 93:279-285

McArdle JF, McKiernan F, Foley H, Jones DH (1991) The current status of Bonamia disease in Ireland. Aquaculture 93:273-278

Medlin L, Elwood HJ, Stickel S, Sogin ML (1988) The characterization of enzymatically amplified eukaryotic 16S-like rRNA-coding regions. Gene 71:491-499

Montes J (1990) Development of Bonamia ostreae parasitosis of flat oyster (Ostrea edulis L.) from Galicia, northwest Spain. In: Cheng TC, Perkins FO (eds) Pathology in marine science. Academic Press, New York, p 223-227

Nicholas KB, Nicholas HB Jr (1997) GeneDoc: analysis and visualization of genetic variation. Available at: http://www. psc.edu/biomed/genedoc

O'Neill G, Culloty SC, Mulcahy MF (1998) The effectiveness of two routine diagnostic techniques for the detection of the protozoan parasite Bonamia ostreae (Pichot et al. 1980). Bull Eur Assoc Fish Pathol 18(4):117-120

Perkins FO (1990) Phylum Haplosporidia. In: Margulis L, Corliss JL, Melkonian M, Chapman DJ (eds) Handbook of Protoctista. Jones and Bartlett Publishers, Boston, p 19-29

Pichot Y, Comps M, Tige G, Grizel H, Rabouin MA (1980) Recherches sur Bonamia ostreae gen. n., sp. n., parasite nouveau de l'huître plate Ostrea edulis L. Rev Trav Inst Peches Marit 43(1):131-140

Rogier H, Hervio D, Boulo V, Clavies C, Hervaud E, Bachere E, Mialhe E, Grizel H, Pau B, Paolucci F (1991) Monoclonal antibodies against Bonamia ostreae (Protozoa: Ascetospora), an intrahaemocytic parasite of flat oyster Ostrea edulis (Mollusca: Bivalvia). Dis Aquat Org 11:135-142

Siddall ME, Stokes NA, Burreson EM (1995) Molecular phylogenetic evidence that the Phylum Haplosporidia has an alveolate ancestry. Mol Biol Evol 12(4):573-581

Sprague V (1979) Classification of the Haplosporidia. In: Perkins FO (ed) Haplosporidian and haplosporidian-like diseases of shellfish. US Natl Mar Fish Serv Rev 41:40-44

Stokes NA, Burreson EM (1995) A sensitive and specific DNA probe for the oyster pathogen Haplosporidium nelsoni. J Eukaryot Microbiol 42(4):350-357

Stokes NA, Siddall ME, Burreson EM (1995a) Detection of Haplosporidium nelsoni (Haplosporidia: Haplosporidiidae) in oysters by PCR amplification. Dis Aquat Org 23:145-152

Stokes NA, Siddall ME, Burreson EM (1995b) Small subunit ribosomal RNA gene sequence of Minchinia teredinis (Haplosporidia: Haplosporidiidae) and a specific DNA probe and PCR primers for its detection. J Invertebr Pathol 65:300-308 
Swofford DL (1999) PAUP - phylogenetic analysis using parsimony, version 4.0. Sinauer Associates, Inc Publishers, Sunderland, MA

Thompson JD, Higgins DG, Gibson TJ (1994) CLUSTAL W: improving the sensitivity of progressive multiple sequence alignment through sequence weighting, position-specific gap penalties and weight matrix choice. Nucleic Acids Res 22:4673-4680

Editorial responsibility: Albert Sparks, Seattle, Washington, USA van Banning P (1991) Observations on bonamiasis in the stock of the European flat oyster, Ostrea edulis, in the Netherlands, with special reference to the recent developments in Lake Grevelingen. Aquaculture 93:205-211

Zabaleta AI, Barber BJ (1996) Prevalence, intensity, and detection of Bonamia ostreae in Ostrea edulis L. in the Damariscotta River area, Maine. J Shellfish Res 15(2): 395-400

Submitted: March 11, 2000; Accepted: May 31, 2000

Proofs received from author(s): September 12, 2000 